\title{
NOVEL FUNCTION OF FLUTTER DISPLAY IN THE BLACK-BACKED WOODPECKER
}

\author{
ANDREW N. STILLMAN, Ecology and Evolutionary Biology, University of \\ Connecticut, 75 N. Eagleville Road, Unit 3043, Storrs, Connecticut 06269; \\ andrew.stillman@uconn.edu
}

FRANKIE TOUSLEY, The Institute for Bird Populations, P.O. Box 1346, Point Reyes Station, California 94956

Reported for a diverse array of avian taxa, flight displays span a wide range of behavioral functions, most commonly associated with territoriality, courtship, or threat defense (Sutherland 1963, Mather and Robertson 1992). Picoides woodpeckers engage in a variety of fluttering aerial displays, including the dramatic "butterfly flight" associated with pair bonding in the Downy (P. pubescens), Hairy ( $P$. villosus), and Red-cockaded (P. borealis) woodpeckers (Kilham 1962, Jackson 1994). However, for many woodpecker species including the Black-backed ( $P$. arcticus), fluttering displays occur in the context of territory defense and function as a threat display to deter intruders (Lawrence 1967, Short 1971, Tremblay et al. 2016). To remain consistent with other published sources (Short 1971, Tremblay et al. 2016) we refer to this behavior as the "flutter aerial display." During the flutter aerial display in Picoides woodpeckers, an individual engages in a quivering, mothlike flight with rapid, shallow wingbeats. The wings are extended outward in line with the body and bowed slightly downward at the distal ends. The tail is spread, revealing the outer rectrices. The flight is usually directed toward an intruder and accompanied by territorial calls.

While monitoring Black-backed Woodpecker nests in burned forests of California's Sierra Nevada, we observed flutter aerial displays between pair-bonded male and female Black-backed Woodpeckers in the absence of territorial intruders. Each of our three observations, representing two pairs, was made in Plumas National Forest during May 2017.

Pair A, 14 May 2017: A male and female were on two separate trees, about $30 \mathrm{~m}$ apart. The female flew to a nearby Jeffrey Pine (Pinus jeffreyi) and perched crosswise on a horizontal branch $0.3 \mathrm{~m}$ out from the trunk. Both the male and female were stationary for 20 seconds before the male flew $12 \mathrm{~m}$, using the flutter aerial display, and landed beside the female. The female adopted a pose with her tail pointed straight out, head tilted slightly upward, and body lowered against the branch-a position termed the "invitation pose" (Kilham 1974). The pair then copulated for 8 seconds, then both individuals flew from the tree toward their nest cavity.

Pair A, 25 May 2017: The female was foraging on the trunk of an Incense Cedar (Calocedrus decurrens) when the male landed on a dead tree $1 \mathrm{~m}$ from her. The female then flew $5 \mathrm{~m}$ to a nearby dead Incense Cedar and perched crosswise on a horizontal branch. After a 15-second pause, the male flew 6 meters, using the flutter aerial display, and landed next to the female, who adopted the invitation pose. Copulation lasted 5 seconds, and both individuals flew off the tree in the same direction.

Pair B, 23 May 2017: A female landed on a horizontal branch of a dead fir tree (Abies sp.) and perched crosswise, $0.2 \mathrm{~m}$ away from the trunk. A male Black-backed Woodpecker flew into view and landed on a Red Fir (A. magnifica) $18 \mathrm{~m}$ away from the female. The male then flew directly at the female, using the flutter aerial display, and landed beside the female on the same branch. The female adopted the invitation pose, and the pair copulated for 8 seconds. The male then flew out of sight, and the female preened in the same location for 3 minutes before flying away.

Each of our observations followed a similar sequence: (1) female perched on horizontal branch, (2) male engaged in the flutter aerial display while flying to the female, (3) 

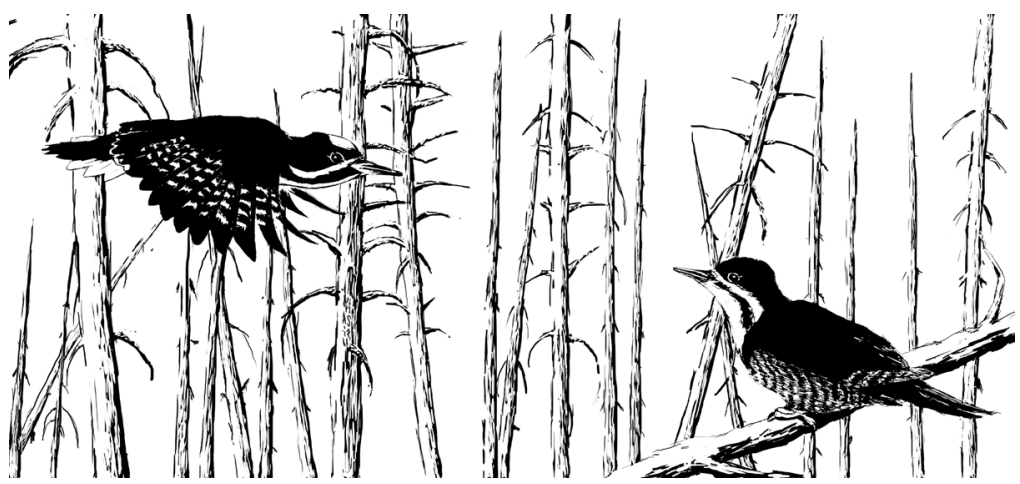

Figure 1. A male Black-backed Woodpecker (on left) engages in the flutter aerial display while flying to copulate with a female (on right) in post-fire forest.

Artwork by Alma Schrage

female adopted the invitation pose, and (4) the male and female copulated. During the flutter aerial display, the male spread his tail to reveal the white outer retrices and flew slowly with shallow, mothlike wingbeats (Figure 1). Unlike agonistic flutter displays, the precopulatory flutter aerial display was not accompanied by any vocalizations. To our knowledge, these observations represent the first reports of the flutter aerial display functioning in a courtship role in Picoides woodpeckers. Male and female Black-backed Woodpeckers perform flutter aerial displays in agonistic situations, but during our observations only males engaged in the behavior prior to copulation.

The flutter aerial display is fully distinct from similar behavioral signals used by other members of the genus Picoides, including the agonistic wing-spreading display (Lawrence 1967, Short 1971) and a mate-pursuit duet flight termed the "butterfly flight" (Kilham 1960, 1962). In the butterfly flight, a male and female pursue each other in a flight characterized by slow, weak wingbeats with wings held well above the horizontal plane in a manner reminiscent of a butterfly's wingbeats. The duo follow each other in a wheeling flight at canopy level (Kilham 1962, Jackson and Ouellet 2002).

During our study, every copulation we witnessed between Black-backed Woodpeckers was preceded by the male's flutter aerial display. Additional observations would be necessary to conclude that these displays always lead to copulation or that copulation is always preceded by a display. Between members of a breeding pair, the flutter aerial display appears to represent a proximate stimulus for copulation and may be a fixed precopulatory ritual. Our observations suggest a novel precopulatory function for the flutter aerial display in the Black-backed Woodpecker.

The field portion of this study took place within national forests and was funded by the Plumas National Forest and the University of Connecticut. We thank Matthew Johnson and Plumas National Forest for providing logistical support. We also thank our dedicated field technicians for their efforts to locate and monitor Black-backed Woodpecker nests: Tina Arthur, Kristen Burgess, Nicholas Parker, and Mitch Poling. Finally, we thank Luke DeCicco and one anonymous reviewer for providing thoughtful comments to improve this manuscript. This is contribution 581 of The Institute for Bird Populations. 


\section{NOTES}

\section{LITERATURE CITED}

Jackson, J. A. 1994. Red-cockaded Woodpecker (Picoides borealis), in The Birds of North America (A. Poole and F. Gill, eds.), no. 85. Acad. Nat. Sci., Philadelphia; doi $10.2173 /$ bna. 85

Jackson, J. A., and Ouellet, H. R. 2002. Downy Woodpecker (Picoides pubescens), in The Birds of North America (A. Poole and F. Gill, eds.), no. 613. Birds N. Am., Philadelphia; doi 10.2173/bna.613

Kilham, L. 1960. Courtship and territorial behavior of Hairy Woodpeckers. Auk 77:259-270; doi 10.2307/4082482.

Kilham, L. 1962. Reproductive behavior of Downy Woodpeckers. Condor 64:126133 doi 10.2307/1365481.

Kilham, L. 1974. Copulatory behavior of Downy Woodpeckers. Wilson Bull. 86:23-34.

Lawrence, L. de K. 1967. A comparative life-history study of four species of woodpeckers. Ornithol. Monogr. 5:1-156; doi 10.2307/40166747.

Mather, M. H., and Robertson, R. J. 1992. Honest advertisement in flight displays of Bobolinks (Dolichonyx oryzivorus). Auk 109:869-873; doi 10.2307/4088161.

Short, L. L. 1971. Systematics and behavior of some North American woodpeckers, genus Picoides (Aves). Bull. Am. Mus. Nat. Hist. 145:1-188.

Sutherland, C. A. 1963. Notes on the behavior of Common Nighthawks in Florida. Living Bird 2:31-39.

Tremblay, J. A., Dixon, R. D., Saab, V. A., Pyle, P., and Patten, M. A. 2016. Blackbacked Woodpecker (Picoides arcticus), in The Birds of North America Online (P. G. Rodewald, ed), no. 509. Cornell Lab. Ornithol., Ithaca, NY; doi 10.2173/ bna.bkbwoo.03. 